\title{
Cooperative Development Model to Promote Tourism in Thailand and Laos in the Border Zone of Ubon Ratchatani Province and Champasak
}

\author{
Serm Ponpern ${ }^{1}$, BoonsomYodmalee ${ }^{1} \&$ Kosit Phaengsoi ${ }^{1}$ \\ ${ }^{1}$ Faculty of Cultural Science, Mahasarakham University Muang District, Mahasarakham 44000, Thailand \\ Correspondence: Serm Ponpern, 713-715 Chayangkul Rd, Muang Ubonratchani, Ubonratchani 34000, Thailand. \\ E-mail: Sermsuptravel@hotmail.com
}

\author{
Received: May 9, 2013 Accepted: June 10, 2013 Online Published: August 30, 2013 \\ doi:10.5539/ass.v9n11p237 URL: http://dx.doi.org/10.5539/ass.v9n11p237
}

\begin{abstract}
Problem Statement: Thailand and Laos are neighboring countries. People living along the border areas often visit one another. The objectives of the study were to examine current circumstances and problems of tourism in the border areas of Ubon Ratchatani Province and Champasak and Cooperative development model to promote tourism in the border zone of Ubon Ratchatani Province and Champasak. Approach: This qualitative research was carried out during 2009-2012. The research data were documentaries and fieldwork collected from 100 sample using a basic survey, observations, and interviews. The data were analyzed qualitatively and the results presented descriptively. Results: Concerning current circumstances and problems of tourism in the border areas of Ubon Ratchatani Province and Champasak, the study found that the cooperation between the two countries for tourism was very limited due to political and economic differences between them. For the cooperative development model to promote tourism in the border areas of the two countries, the study found the followings:

1) Based on the historical background of tourism in the border areas, the study found that there were more Thai tourists visited Laos than did the Lao people visited Thailand. 2) The enhancement of tourism in the border areas covered 8 areas of services: Transportation, hotels, food, sightseeing arrangement tourist attraction, shopping, safety and advertisement and public relations. 3) Cooperation for tourism was based on the governments, the travel companies, and the communities where the tourist attractions were located. 4) Cooperation development to promote tourism with the emphasis on management with government leadership and good law. 5) Cooperative development model to promote tourism based on appropriate content taking into account concrete manner and keeping natural tourist attraction, environmental conservation, equilibrium, tourist impression, and awareness of shared responsibility. Tourism activities should be based on sustainability, keep them in the original condition, expand tourist attraction areas without exploiting natural surroundings and consistent with local people's way of life. The management could predict the future, provide room for comments, and return benefits to everyone involved.
\end{abstract}

Keywords: development model, cooperation, tourism, thailand-laos relations

\section{Introduction}

Cultural tourism gives chances to learn more about people and flashes back to see ourselves related to their surroundings. According to Boonlert Jitthangwattana (2003: 288-290), cultural tourism composed of 6 aspects: The first aspect include historical traces; archaeology and museums; old architecture, buildings, city plan, and ruins; art, craft, sculpture, painting, statue, and carving; religions and religious rites; music, performances, drama, movies, entertainment; languages, literature, and educational system; way of life, clothes, cooking, and eating habits; tradition, folk culture, and festival; and application of technology.Second, the process of environmental education emphasized the importance of the environmental education and ecological culture making awareness of the need to preserve the environment for tourism. Third, business of tourism should put an emphasis on providing services to tourists, obtaining reasonable profit, having environment education, and keeping natural resources for tourism. Fourth, the tourism market designed for quality tourists. Cultural tourism should provide knowledge and experience for tourists' satisfaction as well as preserve natural tourists attraction and environment. Fifth, local community had full participation in cultural tourism and obtain reasonable income for life quality improvement. Sixth, the awareness related to tourism included a provision of knowledge to all involved in tourism and environment winning love and cherish of cultural resources and environment winning love and 
cherish of cultural resources and environment. Cultural tourism is also defined as a journey to cultural tourist attractions, such as, ancient ruins, religious places, ways of life, festivals, traditions, art, and local culture. Cultural tourism should take into account the impact on people and society. If possible, each community should keep appropriate traditions and revise what was or were necessary keeping traditional forms and functions so that the value of local traditions and culture can be restored. Thailand and Laos have similar cultural tourism. In Thailand, Tourism Authority of Thailand (T.A.T.) has an important role in cultural tourism assigning 8 areas of activities. They include transportation, hotels, food and restaurants, tourist services, tourist attractions, gift shops and souvenirs, safety, and publishing and advertising, As for Laos, there was no clear direction concerning organization responsible for cultural tourism, yet analyzed with reference to Thailand.

Thailand and Laos are neighboring countries. The 1893 Franco-Siamese War, ended with France taking over Laos located on the left-hand side of the Mekong River. The Thai-Lao or Isan people living in the right-hand side of the River and Lao people were then close neighbors like close cousins. Once separated from one another, the people in Thailand and Laos were not very close with each other as they once were. The government systems also contributed to differences between the two countries. On the contrary, the Thai and Lao people still maintain close relations based on cultural similarities and ethnic background. Regardless of whatever reasons, the Thai people including the Isan people have been more economically progressed than the people living in Laos. The economic differences between them play an important role in cultural tourism in Ubon Ratchatani Province and Champasak as follows:

\subsection{Cultural Tourism between Thailand-Laos Prior to the Year 2000}

The cultural tourism between Thailand and Laos prior to 2000 corresponded with political relations between the two countries which were often up and down. The border conflicts erupted at Ban Rom Klao-Bo Tan (November. 1987-February, 1988), Chong Mek- Wang Tao (July. 2000), and Nicole (March-April. 2000). Due to such causes, some people in Laos felt bad toward Thailand and its people. The Lao people thought that the Thais looked down at them the most (Khien Teerawit. 2001: 97-184). The relationship between Thailand and Laos went sour for some time; the cultural tourism was also affected.

Regardless of whatever reasons, the Lao-Thai or Isan people could maintain their relationship with the Lao people based on the cultural similarities and ethnic background. The Lao-Thai or Isan people have been more economically progressed than the people in Laos. The economic differences between the two countries play an important role in countries play an important role in cultural tourism in the border zone of Ubon Ratchatani Province and Champasak and was corresponded with the political relations between the two countries. Despite poor relationship between them, the social and cultural context shared similarities, each learned something from one another through media mainly television and newspaper. Thai goods were sold in Laos and the Thai tourists had good time in Laos. They treated each good time in Laos. They treated each other as close kins, like brothers and sisters. As for cultural tourism, Thailand to some extent, went ahead of Laos due to having Thailand Tourism Authority. Thailand had set standards of tourism elements, such as, hotels, accommodation, transportation, food, and safety. Laos, on the other hand, worked hard since 2000 to bring about change and improvement of cultural tourism.

\subsection{The Thai-Lao Cultural Tourism during 2000-Present}

Lao government declared the year 2000 the year of tourism through various media. Since then touristspoured into Laos. There were 8 travel agencies in Champasak but 0nly 3 were located there. The government set up rules and regulations concerning the entering and leaving the country and approved contracts maintain their relationship with the Lao people based on the cultural similarities and ethnic background. The Lao-Thai or Isan people have been more economically progressed than the people in Laos. The economic differences between the two countries play an important role in cultural tourism in the border zone of Ubon Ratchatani Province and Champasak and was corresponded with the political relations between the two countries. Despite poor relationship between them, the social and cultural context shared similarities, each learned something from one another through media mainly television and newspaper. Thai goods were sold in Laos and the Thai tourists had good time in Laos. They treated each other as close kins, like brothers and sisters. As for cultural tourism, Thailand to some extent, went ahead of Laos with foreign travel compares. Those located in Champasak and Ubon Ratchatani Province were also allowed to provide services to tourists. For the Thai travel agencies had to submit travel plans and names of tourist within 7 days in advance. For the Lao travel agencies, they were asked to pay some fees to National Tourism Fund.

As more and more tourists began to cross Thai-Lao border at Chong Mek, some chose not to use travel agency or a tourist company. They paid at the border check-point by themselves. There was a lot of confusion at the 
beginning. Some tourists did not know exactly what to do. A tourist company did not know how much it should charge each tourist or a group of tourists entering the country at the check-point. Some tourist groups claimed that they went to Laos for the purposes of Buddhist traditions, such as, Pha Pa, Kathin, study trip or educational exchange program sponsored or hosted by government officers. The government did not know what to do except providing help or services. Some travel companies went on as far as competing with one another taking tourists and complaining that they were treated unfairly.

To go about solving the problems, travel companies in Champasak established an association, known as Business Travel Bureau on November 4, 2005 providing professional services under the direction of group representatives. The company worked very closely with the tourist police and Champasak Tourism Bureau.

The strengths from having an association dealing with Champasak Tourism Bureau were several.

1) The Bureau brought all travel agencies were under one umbrella.

2) Tourism related problems were or could be promptly solved.

3) Charges were unified and services done professionally.

4) Meeting of all concerns nationally and internationally could be arranged as needed corresponding with the National Tourism and government policy on tourism.

5) Many travel agencies received recognition and awards from government as well as the National Tourism Organization.

6) In total, these were 18 travel agencies in Champasak, 8 established locally, 10 branches.

The weakness found were that the Business Tourism Bureau could not fully follow its own plans; some travel agenciesand branches could not fully become members of the Business Travel Bureau. Some travel agencies offered tourist services and charged illegally. The service charges were often lower than normal ones.

The negative impact found that the listed travel agencies in Thailand and Laos were affected directly; the national tourism found and government income drawn from tourism decreased; statistics on tourism were not accordance with reality. Business people took advantage of a huge gap between the people and travel agencies either breaking or abiding the laws on tourism.

Each country had its own tourism model. The Thai tourism model composed of 4 aspects: areas, management, tourist activities, and organization. The management of tourism could be done officially and semi-private and public. The first tourism model offered a guideline for responsible organizations carrying out tourism. As for the latter, the model offered directions and role for tourism management. As for Laos, the government had policies concerning promotion of tourism, tourism management plan, and world tourism organization, Emeral Triangle Tourism, and foreign investment on tourism in Laos. In case of tourism development, several aspects needed development: tourist sites and access, tourist season, souvenirs, international cooperation, personal development, advertisement, support for backpackers, and agro-tourism.

\section{Objectives}

1) To examine current circumstances and problems of tourism in the border areas of Ubon Ratchatani Province and Champasak, Laos.

2) To examine cooperative development model to promote tourism in the border area of Ubon Ratchatani Province and Champasak, Laos.

\section{Approach}

This qualitative research was carried out from 2009-2012 at Ubon Ratchatani Province, Thailand and Champasak, Laos. The research data included documentaries and fieldwork collected from 100 sample using a basic survey, observations, and interviews. The data were analyzed qualitatively and the results presented descriptively.

\section{Results}

Based on the research objectives, the results found were as follows:

Upon the current circumstances of tourism in border areas of Ubon Ratchatani Province, Thailand and Champasak, Laos, the study found as follows:

1) The peopleliving in the border zone of the areas above failed to understand the certain rules and regulations concerning the border crossing for short and long term tourism. 
2) Goodsmuggling and drug trafficking were common due to the remote areas. Suranaree Armed Forces and Border Police were called in to preventsuch illegal practices. There was a need for more armed forces and border police.

3) Phibun Mangsahan Customs Division was so remote. It was located 45 kilometers from Chong Mek Customs. Export and imported goods could be illegally smuggled.

4) The customs building and new government building center were to be completed due to community intrusion of building construction.

5) The frees for going in and out at the customs using border passes or passports were often not clear.

6) Tourists and travel agencies going to Laos as tour-groups through Lao travel agencies often paid uncertain or higher amount of fees.

7) International tourist buses connecting Ubon Ratchatani Province, Thailand and Pakse, Laos should extend their destination to the Kon Phapheng Waterfall adding another bus routes in Laos.

Forproblems of tourism in the border areas of Ubon Ratchatani Province, Thailand and Champasak, Laos, the study found 8 major problems.

a. Vehicle and Laws

Most travel agencies in the border zone of Ubon Ratchatani Province and Champasak used buses and drivers from Thailand. Large Thai buses could not go to tourist attractions, such as, Li Phi Waterfall and Prasat Wat Phu due to road size and conditions. The drivers often failed to follow the Lao driving law. They had to pay the fine. The laws concerning tourism in Laos were often not clear for the Thai travel agencies, tourist guides, and managers of the Thai travel agencies.

b. To promote activities related to hotel accommodation

The Hotels in Laos at the time of the research were a little bit lower than standard especially the managerial and marketing levels. Sometimes the rules or regulations concerning tourism were changed without notice.

c. Foods and Drinks

The foods and drinks served remained to be improved due to management and cooking. Improvement was needed for restaurants, and utensils, and waitress' manners. They did not know how to provide services to the V.I.P. tourists.

\section{d. Travel Services}

Most of the travel arrangements should follow the agreement or plans set prior to the beginning of each trip. Most tourist plans were made or offered by Thai travel agencies and they were apt to change due to various seasons, such as, weather, floods and other natural disasters. The problems arose included food prices, transportation, and time or duration.

\section{e. TouristAttractions}

The problems found included inadequate or up-to-date maps, personnel of each tourist attraction, tourist information center, and submitting complaints.

\section{f. Souvenirs}

Although most gift or souvenirs shops were a little bitlower than standards, their souvenirswere sold with fair prices and they could be paid for by Thai bahts. The standardsouvenirs shops sold their gifts in American dollars. Most shoppers believed that they paid more money than they did with the Thai bahts.

g. Safety for Personal Assets and Health

Laos has been famous for its peaceful living, political stability, and tidiness (Faculty of Accounting and Management, Mahasarakham University. 2010: 28) The people believed in Buddhism, seniority, and local and national leaders. The police played important role in keeping law and order in Laos. The poverty, however, kept the majority of people from having good health. The government at the time was trying to improve the medical services.

\section{h. Advertisements and Public Relations}

Thailand and Laos, so far, had not done advertisements and public relations concerning tourism together. Tourism in Laos had not much to do with the government. By law, local leaders could decide for their communities and their country without the intervention of the central government. The Thai government, on the 
other hand, involvedin almost everything including the Tourism Authority of Thailand.However, cooperation between Thailand and Laos could be traced back to cooperation on tourism under the Greater Mekong Sub-Region (GMS) in which 6 nations were members: Thailand, Myanmar, Laos,Cambodia, Vietnam, and China (Yunnan). Also cooperation among member countries was mentioned in Ayeyawadi Cho Phraya-Mekong Economic Cooperation Strategy (ACMECS): Thailand, Myanmar, Cambodia, Vietnam, and Laos (Phibun Mangsahan Customs Division. 2003: 35).

Cooperative development model to promote tourism in the border areas of Ubon Ratchatani Province, Thailand and Champasak Laos.

In the past, the Thai and Lao people who lived in the given areas often crossed the border visiting each other as if they were close kins or relatives. Law or related regulations then were not clear. As cultural tourism became popular worldwide, problems of tourism could be solved by promotion of related activities and drawing up cooperative development model. Promotion of Tourism in the Border Areas

1) To promote activities related to vehicles by road improvement especially the ones to and from the tourist attractions; installing signs, and providing vehicles needed.

2) To promote activities related to hotel accommodation by providing standard rooms and price; training of personnel; and low-interest bank loans.

3) To promote activities related to food and drinks by improvement of Chef's cooking skills; dissemination of food quality and safety to restaurants located in or near tourist attractions; and providing low-interest bank loans.

4) To promote activities related to travel services by assisting training of personnel, such as, tourist guides; holding public events, such as, competition for outstanding tourist guides.

5) To promote activities related to tourist attractions by installing signs of tourist attractions; the signs should be in Thai, Lao, and English; organizing training workshops for tourist guides and local resource persons.

6) To promote activities related to souvenirs by assisting of setting up shops and training shopkeepers selling souvenirs.

7) To promote activities related to safety of personal assets and health by holding training workshops for local people assisting local tourism.

8) To promote activities related to advertisements and public relations by getting local leaders or entrepreneurs to participate in providing appropriate tourist services in which three groups of people could readily help: private sector, government, and local community.

Cooperative Development Model promoting tourism in the given areas were as follow:

1) The governments of Thailand and Laos should act as sole leaders making plans for cooperation between the two countries by enacting laws and regulations needed for tourism.

2) The sectors participating cultural tourism (government, tour agencies or companies, and local community) should discuss over as well as look for ways to solving such problems and develop tourism systematically.

3) The content areas needed cooperation development model take into consideration 4 areas, namely, tourist attraction areas, management, impressive activities, the consciences of the organizations and people involved.

\section{Discussion}

The discussion focused on 3 aspects: similarities or differences with previous studies; points enabled the development of cooperation on tourism between the given countries.

1) On the similarities with previous studies, the study proposed a cooperative development model promoting cultural tourism in the border area of Ubon Ratchatani Province, Thailand and Champasak, Laos, whereas Siriwan Sereerat (1997: 111-141) found strategic plans connecting tourism in Ubon Ratchatani Province, Thailand and Champasak, Laos. Sommai Chinnak and others (1997) found various tourist activities in Thailand and Laos.

2) For points enabled the development of cooperation on Tourism between Thailand and Laos, the study found that Thailand had opportunities to invest in Tourism in Laos due to a contiguous border. Laos had also received assistance from Thailand. According to the World Bank, the economic growth of Laos in 1999 was $6.4 \%$ and was second to China. Logistically, Laos is readily linked with Vietnam and China. Most large towns in Laos were ready to invest more on tourism. Such a finding was in agreement with Faculty of Accounting and Management, Mahasarakham University. 2010: 27-31 that many foreign investors invested in Vientiane, Luang 
Prabang, Pakse, and others. Laos also offered privileges to foreign investors investing in Laos, preferably in all parts of the country for income distribution.

3) For current situations affecting cooperation on tourism between Thailand and Laos, the study found that the two countries had mutual relations continuously. Cases supported such aspect included the following and they were in agreement with Faculty of Accounting and Management (Mahasarakham University. 2010: 36)

4) Due to close cultural and ethnic relations, the Thai investors in Laos did not have to worry about cultural conflicts. The mutual relations brought comport to investors.

5) The Thai government and private sector provided to Laos; the aid was not huge but it had no string attached making the Lao government and people were at ease. One of such aid was related to nutrition and health care.

6) Since the mutual relations between Thailand and Laos had been developed continuously. Although problem, big and small, occurred all along, they were solved more profoundly. The problems included border conflicts, electricity, trade, sugar, and industry.

\section{References}

Boonlert, J. (2003). Development of Sustainable Tourism. Bangkok: Press and Design Limited Company.

Faculty of Accounting and Management. (2010). Thai-Lao Economic Partnership Strategy. Maha Sarakham: Mahasarakham University.

Teerawit et al. (n. d.). Relations between Thailand-Laos in the Eyes of Lao People. Bangkok: Institute of Asian Studies, Chulalongkorn University.

Phibun Mangsahan Customs Division (2003). Report of Operation for Fiscal Year, 2553. Phibun Mangsahan: Office of Phibun Mangsahan Customs Division.

Sereerat, S. (1997). A study for Tourism Strategic Planning Connecting UbonRatchatani Province and Chong Mek, Laos. in Thailand Border Tourism and Neighboring Countries, 111-141. Bangkok: P. S. Print.

\section{Copyrights}

Copyright for this article is retained by the author(s), with first publication rights granted to the journal.

This is an open-access article distributed under the terms and conditions of the Creative Commons Attribution license (http://creativecommons.org/licenses/by/3.0/). 